\title{
Environmental health needs and launching of an environmental health protection unit in Pakistan
}

\author{
M.Z.A. Khan, ${ }^{1}$ B.M. Kazi, ${ }^{2}$ K.M. Bile, ${ }^{3}$ M. Magan ${ }^{3}$ and J.A. Nasir $^{2}$
}

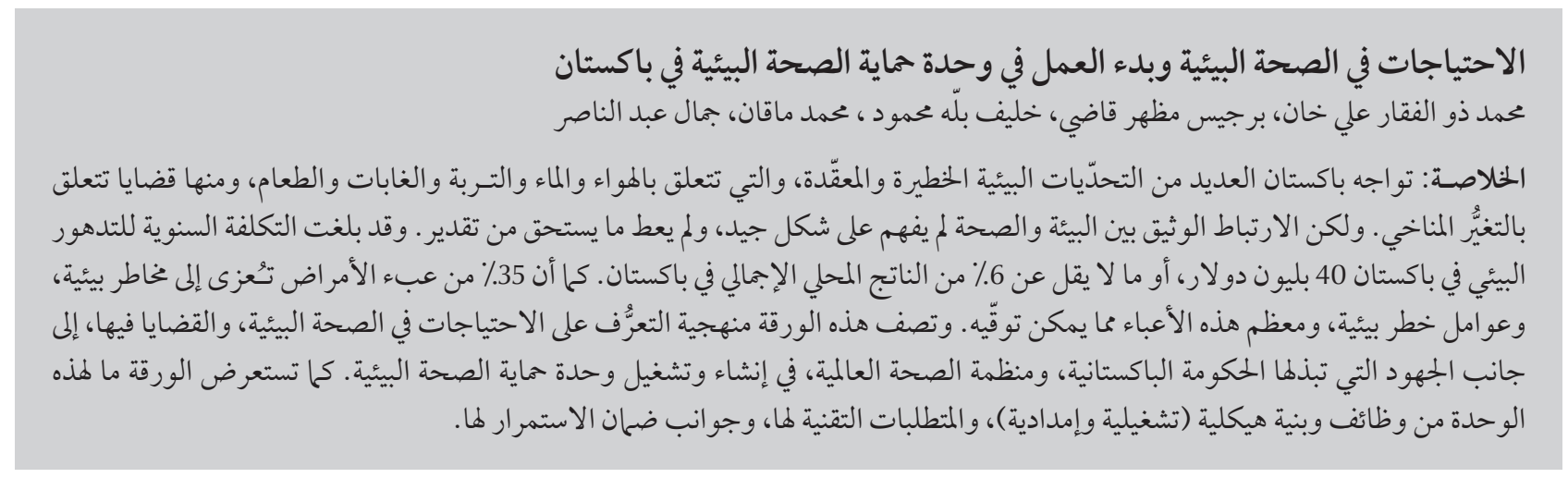

ABSTRACT Pakistan is seriously confronted by many complex and difficult environmental challenges related to air, water, soil, forests and food including issues such as climate change. The close link between environment and health is neither well understood nor appreciated. The annual cost of environmental degradation in Pakistan has been estimated to be around US $\$ 4.0$ billion or at least $6 \%$ of the country's GDP. Up to $35 \%$ of the burden of disease is attributable to environmental hazards and risk factors and most of this burden is preventable. A systematic process for identifying environmental health needs and issues as well as the efforts made by the government of Pakistan and the World Health Organization in establishing and launching an environmental health protection unit are described. Also presented are the mission, functions, structure (operational and logistical) and technical requirements as well as sustainability aspects of the environmental health protection unit.

Besoins relatifs à la salubrité de l'environnement et ouverture d'un bureau de protection de la salubrité de I'environnement au Pakistan

RÉSUMÉ Le Pakistan est sérieusement confronté à de nombreux problèmes environnementaux, complexes et difficiles, qui concernent l'air, l'eau, la terre, les forêts et les denrées alimentaires, et incluent le changement climatique. Le rapport étroit entre environnement et santé n'est pas bien compris et son importance est mal perçue. Le coût annuel de la dégradation de l'environnement au Pakistan a été estimé à environ quatre milliards USD et à $6 \%$ du PIB du pays au minimum. Les risques et les facteurs de risques environnementaux représentent jusqu'à $35 \%$ de la charge de morbidité, qui est en grande partie évitable. Cet article décrit un processus systématique d'identification des besoins et des problèmes relatifs à la salubrité de l'environnement, ainsi que l'action du gouvernement pakistanais et de l'Organisation mondiale de la Santé pour mettre en place un bureau de protection de la salubrité de l'environnement. La mission, les fonctions, la structure opérationnelle et logistique et les règles techniques de ce bureau sont également présentés, ainsi que les aspects relatifs à sa viabilité. 


\section{Introduction}

Pakistan is one of the 22 Member States of the World Health Organization's (WHO's) Eastern Mediterranean Region (EMR). Its current population of around 170 million makes it the most populous country in the Region [1]. The country is seriously confronted by many complex and difficult environmental challenges related to air, water, soil, forests, food and issues such as climate change as well as a double burden of disease due to communicable and noncommunicable diseases [2-6]. Several agenciesaremandated for the protection of environment. However none of them is responsible for protecting humans from the adverse health effects of poor environment. The close link between environment and health is neither well understood nor appreciated. Pakistan has several national policies, guidelines, laws, ordinances, rules and regulations related to the protection of the environment; however their implementation and enforcement are very limited $[2,4]$. The annual cost of environmental degradation, in the country, has been estimated to be around US\$ 4.0 billion or at least $6 \%$ of the country's GDP [2]. The two most significant causes of environmental degradation have been identified as: air pollution, both indoor and outdoor, making up 50\% of the total environmental damage and resulting in acute respiratory infections and premature mortality; and inadequate water supply, sanitation and hygiene, accounting for $30 \%$ of the total environmental damage, causing diarrhoeal and other waterborne diseases $[2,5,7]$.

A systematic process used for identifying environmental health needs and issues as well as the efforts made by the government of Pakistan and WHO in establishing and launching the environmental health protection unit in Pakistan are described. A brief summary of its key mission, functions, structure (operational and logistical) and techni- cal requirements as well as sustainability aspects are also presented.

Need \& process for
establishing the
environmental health
protection unit

The WHO's Regional Office for the Eastern Mediterranean (WHO/ EMRO) has been providing technical assistance and support to the federal Ministry of Health in Pakistan in planning and implementing its developmental activities as well as meeting urgent environmental health needs in emergencies and disasters. A team of experts from WHO came to Pakistan in 2009 and developed a "road map" broadly defining the scope, need and functions of an environmental health protection unit. As a follow-up to the team findings and recommendations, the WHO office in Islamabad recruited the services of an international expert in environmental health (a former Director of WHO's Centre for Environmental Health Activities) to further assist the government of Pakistan in determining the feasibilityof an environmental health protection unit and carrying out efforts towards its initiation and establishment.

An overview of various environmental health variables and their status in the country indicates that the environmental health situation in Pakistan is not very satisfactory (Table 1 ).

A meta-analysis of four major environmental health-related issues - water safety, air pollution, heath care waste and food safety-was carried out highlighting the main focus of the surveys/studies conducted by various agencies and institutions. The analysis also included the key findings and gaps (Table 2).

World Bank and WHO studies indicate a substantial annual economic loss and burden of disease in Pakistan resulting primarily from the two major environmental factors, air pollution and water safety (Table 3 ).

A comparative analysis of the seven countries of the Region with the lowest environmental health indicators shows that Pakistan is still lagging behind in some of the key environmental health indicators in meeting the WHO's Health for All targets as well as the United Nations' Millennium Development Goals (Table 4).

Considering the current situation in environmental health, the government felt that there was an urgent need to have a close collaboration, coordination and cooperation mechanism between health and other sectors dealing with environmental risks and thus decided to establish an environmental health protection unit in the Ministry of Health, Islamabad. In order to jump start the process, "seed funds" and technical assistance and support were provided by the WHO office in Islamabad. The unit was officially launched in March 2010.

\section{Environmental health protection unit: mission, functions and requirements}

A brief summary of the environmental health protection unit's mandate, functions and structure, priority areas, linkages with other agencies and operational needs are described below.

\section{Mission}

The mission of the unit is to contribute to the protection of human health, prevention of diseases attributable to environmental risk factors, promotion of healthy environment and improvement in the quality of life.

\section{Functions}

Its main functions will be to: serve as the health sector front line body that will ensure that health protection concerns are addressed through action by other 


\begin{tabular}{|c|c|}
\hline Variable & Status \\
\hline Overall environmental health situation in Pakistan & Not very satisfactory \\
\hline Major environmental health issues & $\begin{array}{l}\text { Water safety, health care waste, air pollution, and food } \\
\text { safety }\end{array}$ \\
\hline Mandate of agencies managing environmental risks and hazards & $\begin{array}{l}\text { Several agencies responsible, but none have the mandate of } \\
\text { protecting human health from such hazards }\end{array}$ \\
\hline $\begin{array}{l}\text { Coordination and collaboration between environmental and } \\
\text { health agencies and with other stake holders }\end{array}$ & Very little \\
\hline $\begin{array}{l}\text { Implementation and enforcement of existing laws, rules and } \\
\text { regulations }\end{array}$ & Very weak and limited \\
\hline Level of awareness of the linkage between environment and health & Very little \\
\hline Environmental health as a priority in the country & Low as reflected by limited annual budget allocations \\
\hline Availability of human resources in environmental health & Extremely limited \\
\hline $\begin{array}{l}\text { Engagement of health sector in motivating action by other sectors } \\
\text { for health protection }\end{array}$ & Very limited, needing further efforts and urgent action \\
\hline $\begin{array}{l}\text { Availability of evidence based information in environmental health } \\
\text { for sound policies and decision making }\end{array}$ & Extremely limited \\
\hline Regular surveillance and monitoring systems for air, water and food & Very limited \\
\hline $\begin{array}{l}\text { Availability of environmental management tools, resources and } \\
\text { infrastructure to provincial and local authorities }\end{array}$ & Very limited \\
\hline
\end{tabular}

sectors on environmental risk factors as well as contribute to developmental policies, rules, guidelines, protocols, setting of national standards and legislation and programmes dealing with environmental risks factors; undertake monitoring and surveillance of environmental health factors (e.g. water); generate evidencebased information for corrective action and linkages to public health; and implement public awareness and education programmes and campaigns as well as conduct evidence-based advocacy to motivate health protection action by other sectors.

The unit will be headed by a coordinator, supported by four technical staff, experts in different environmental health areas, such as water safety, environmental risk assessment and management, information management and networking. It is expected that a technical advisory group will be established that would ensure compatibility and complementary action and coordination amongst the key responsible agencies which contribute to environmental health, especially the ministries of health and environment.
The technical advisory group would advise on the development of the environmental health protection unit and guide its work.

\section{Priority areas of focus and structure}

The following seven priority areas and environmental health risk factors have been identified for action by the environmental health protection unit: drinking water quality, sanitation (including solid waste) and hygiene; air pollution (indoor and outdoor); health care waste and hazardous wastes; chemicals and pesticides; environmental heath impact assessment; environmental health aspects of emergencies and disasters; and food safety.

The unit will comprise four departments, namely the Water Safety, Environmental Sanitation and Hygiene Department (WSH); the Environmental Health Surveillance and Monitoring, Risk Assessment and Management Department (ERM); the Chemical and Food Safety Department (CFS); and the Information, Networking and Data Management Department (INM).
However initially, due to limited resources, it was considered appropriate to start with only the WSH and ERM departments, focusing on the two major priority issues - water safety and health care waste management - for the coming three years.

\section{Linkages and coordination with other agencies}

The environmental health protection unit's operations will require very close coordination, collaboration and networking with a multitude of agencies dealing with environmental hazards and risk factors as well as with those which offer potential collaboration to the environmental health protection unit in its priority areas of focus in environmental health (Figure 1). Additionally, the environmental health protection unit will also draw on all the existing and available capacities - training, analysis, research, teaching, available networks, etc. - in other agencies, ensuring transparency, complementing and supporting activities (planned to be implemented by others) and avoiding duplication of any efforts. 


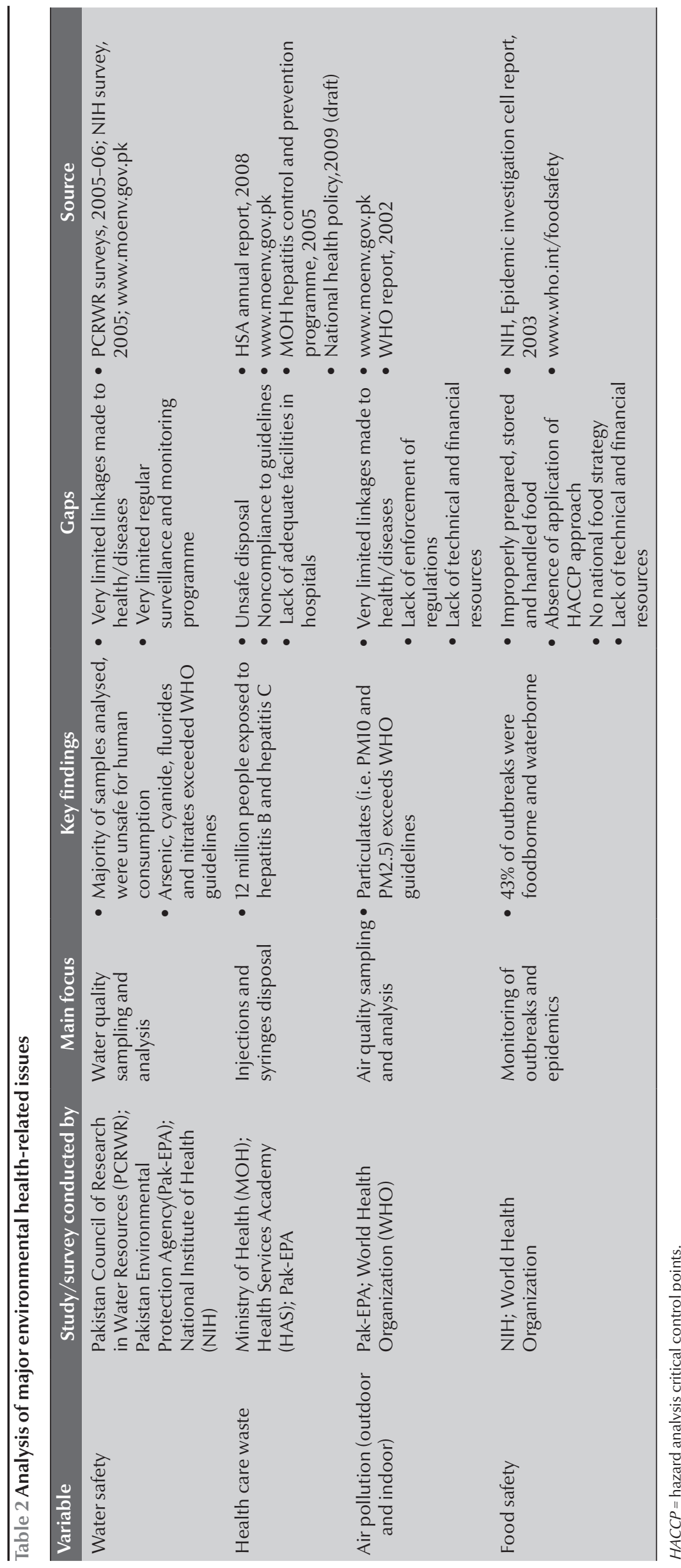

\section{Operational requirements}

In order for this unit to function and operate efficiently and effectively, its basic and essential requirements (staffing, office space, information system, laboratory infrastructure and logistical facilities), detailed terms of reference and duties of the staff have been prepared. Regarding the sources of funding and the sustainability of environmental health protection unit, it was agreed with the Pakistan Ministry of Health, that the initial "seed funds" would be provided by WHO; however the major support and sustainability of the environmental health protection unit will depend upon the availability of resources from the Ministry of Health and donors. It was also considered appropriate that fundraising proposals be prepared and promoted to donors. Detailed plans of work for one year and three years have been developed. The one-year plan, starting in 2009 and costing about US $\$ 437500$, focuses on water safety and for managing health care waste (especially safe disposal of syringes, sharps and needles), while the three-year plan, 2009-12, costing US\$ 1115000 deals primarily with water safety and safe handling and management of health care waste, but also includes activities related to air pollution (especially indoor), and food safety.

\section{Key role of the environmental health protection unit}

The role of the environmental health protection unit has been very carefully designed to address the urgent and priority environmental health issues, affecting human health in both the rural and urban settings in the country. Key environmental health issues, where the unit has already initiated and/or planned practical interventions, are listed below. 


\begin{tabular}{|c|c|c|c|c|}
\hline Environmental issue/factor & $\begin{array}{c}\text { Economic loss, in US\$ } \\
\text { billion (\% GDP loss) }\end{array}$ & Resulting diseases & $\begin{array}{c}\text { Annual burden of disease } \\
\text { (DALYs/deaths) }\end{array}$ & Source \\
\hline $\begin{array}{l}\text { Inadequate water supply, } \\
\text { sanitation and hygiene } \\
\text { (water safety) }\end{array}$ & $\begin{array}{c}1.4 \\
(1.81 \% \text { of GDP) }\end{array}$ & $\begin{array}{c}\text { Diarrhoea, typhoid, } \\
\text { hepatitis, intestinal worms, } \\
\text { dengue fever, and others }\end{array}$ & $\begin{array}{c}1.6 \text { million diarrhoea DALYs } \\
900000 \text { typhoid DALYS } \\
250000 \text { infant deaths }\end{array}$ & $\begin{array}{l}\text { World Bank, } \\
2006 \\
\text { WHO, } 2006\end{array}$ \\
\hline \multicolumn{5}{|l|}{ Air pollution } \\
\hline Outdoor & $\begin{array}{c}0.8 \\
\text { (1.08\% of GDP) }\end{array}$ & $\begin{array}{l}\text { ARI, heart ailment, lung } \\
\text { cancer, chronic bronchitis } \\
\text { and others }\end{array}$ & $\begin{array}{l}22000 \text { premature adult deaths } \\
\text { DALYS lost }=163432\end{array}$ & $\begin{array}{l}\text { World Bank, } \\
2006 \\
\text { WHO, } 2006\end{array}$ \\
\hline Indoor & $\begin{array}{c}0.75 \\
(1.0 \% \text { of GDP })\end{array}$ & $\begin{array}{l}\text { ARI, chronic bronchitis, } \\
\text { cataracts, tuberculosis, low } \\
\text { birth weight, and others }\end{array}$ & $\begin{array}{l}40 \text { million cases ARI } \\
28000 \text { deaths/year }\end{array}$ & $\begin{array}{l}\text { World Bank, } \\
2006\end{array}$ \\
\hline Exposure to lead & $\begin{array}{c}0.53 \\
(0.72 \% \text { of GDP) }\end{array}$ & $\begin{array}{l}\text { Hypertension, blood } \\
\text { pressure, heart disease, } \\
\text { and others }\end{array}$ & DALYS lost = 355918 & $\begin{array}{l}\text { World Bank, } \\
2006\end{array}$ \\
\hline
\end{tabular}

$G D P=$ gross domestic product; $D A L Y_{S}=$ disability-adjusted life years; $W H O=$ World Health Organization; $A R I=$ acute respiratory infection .

\section{Water safety}

The government has attempted to provide safe water to its population under a national project called "Clean Drinking Water for All” [2]. This project has not been, so far, very successful due to inadequate water treatment facilities, and better management, improved infrastructure and sufficient resources for repair and maintenance of such facilities are required. However, about $70 \%$ of the population still relies on contaminated water sources, and $60 \%$ of the rural schools and health centres lack safe water and adequate sanitation facilities, thus putting schoolchildren, patients, and health care workers at increased health risk [8-11]. Waterborne diseases and outbreaks continue to rise [9]. The environmental health protection unit plays an important role in providing the needed technical support in identifying, assessing and promoting appropriate technologies for maintaining the safety of water at the household level through its strong waterquality surveillance and monitoring capacity. This should result in an overall reduction of diarrhoeal and waterborne diseases. The unit has also undertaken an initiative of mapping of drinking-water quality and linking it to health in various districts in the country. Appropriate remedial and mitigation measures as well as awareness-raising approaches will be proposed for safeguarding the health of the affected communities.

\section{Health care waste management}

The federal Ministry of Environment, as part of its mandate, has published the "Health Care Waste Management Rules, 2006” (approved 2005) for hospitals. However very few of them are actually follow these rules [12-15]. Recent studies carried out in Rawalpindi and Islamabad have demonstrated that the toxic emissions from improperly operated and managed hospital incinerators cause serious health problems for residents [16]. Unsafe management

\begin{tabular}{|c|c|c|c|c|c|c|c|}
\hline $\begin{array}{l}\text { Indicator (demographic, social and } \\
\text { environmental) }\end{array}$ & Afghanistan & Djibouti & Pakistan & Palestine & Somalia & Sudan & Yemen \\
\hline Total population (million) & 24.5 & 0.72 & 170 & 3.76 & 7.96 & 37.2 & 21.5 \\
\hline Urban population (\%) & 22 & 83 & 35 & 57 & 36 & 38 & 29 \\
\hline Population under 15 years (\%) & 40.0 & 40.0 & 37.8 & 45.7 & 44.4 & 41.3 & 45.0 \\
\hline $\begin{array}{l}\text { Population with access to sustained } \\
\text { water resource (\%) }\end{array}$ & - & 84 & 90 & 81 & 29 & 56 & 31 \\
\hline $\begin{array}{l}\text { Population with access to improved } \\
\text { sanitation (\%) }\end{array}$ & 67 & 85 & 54 & 97 & 37 & 31 & 23 \\
\hline $\begin{array}{l}\text { Ministry of health budget as \% of } \\
\text { government budget }\end{array}$ & 3.3 & 14.3 & 1.5 & - & - & 7 & 5.6 \\
\hline Life expectancy at birth (total years) & 46.0 & 44.1 & 65.0 & 72.5 & 47.0 & 58.0 & 61.1 \\
\hline Infant mortality rate (per 1000 live births) & 129.0 & 67.0 & 78.0 & 24.2 & 86.0 & 81.0 & 68.5 \\
\hline $\begin{array}{l}\text { Under-five mortality rate (per } 1000 \text { live } \\
\text { births) }\end{array}$ & 191.0 & 94.0 & 94.0 & 28.3 & 135.0 & 112.0 & 78.2 \\
\hline
\end{tabular}


EHPU's priority environmental health issues

Institutions offering potential collaboration with

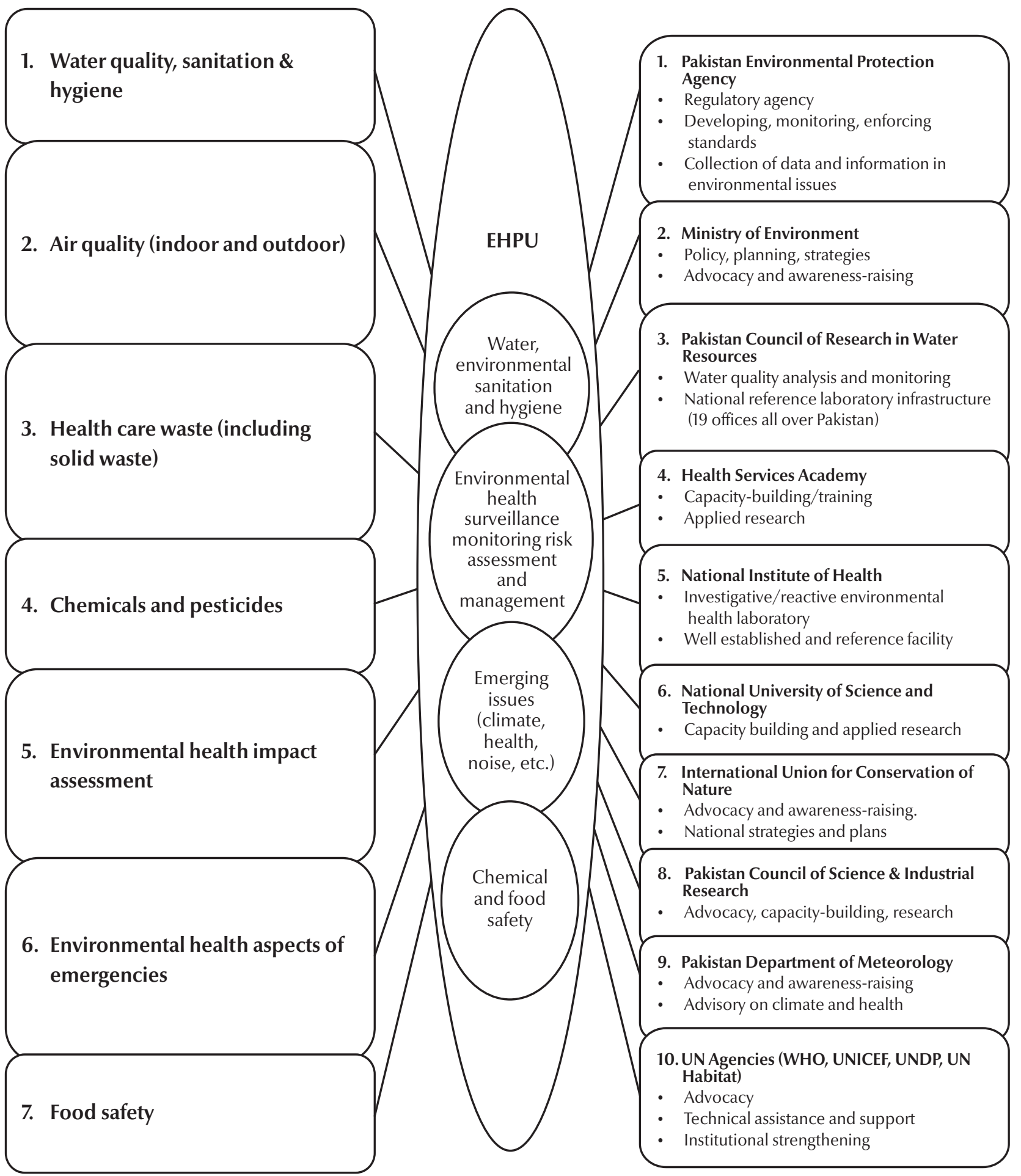

Figure 1 Environmental health protection unit (EPHU) and its linkages with other environment related agencies and institutions

of health care waste, especially the unsafe injection practices component, has seriously resulted in the rise of hepatitis
$\mathrm{B}$ and hepatitis $\mathrm{C}$ cases $[13,15,17]$. The environmental health protection unit has already selected and sponsored three hospitals as pilots for identifying and promoting the best practices for hospital waste management. 


\section{Food safety}

Foodborne diseases remain responsible for high levels of morbidity and mortality in Pakistan, but particularly at risk are infants and young children, the elderly and the immunocompromised [18]. This is confirmed by National Institute of Health (Islamabad) studies indicating that the highest number of outbreaks are of foodborne origin [9]. The environmental health protection unit, as part of its workplan, will be promoting the concept of hazard analysis critical control points (HACCP) systems in reducing the incidence of foodborne diseases.

\section{Air pollution}

Air pollution, both indoor and outdoor, is the highest contributor to the environmental burden of disease in Pakistan [2]. Pakistan Environmental Protection Agency studies indicate that air quality in most cities does not meet WHO Air Quality Guidelines [19]. The extensive data and information collected are not linked to the health situation of the population living in these affected areas. One of the major goals of the environmental health protection unit is to maintain a close link between the ministries of health and environment as well as develop and promote evidencebased information.

\section{Conclusion}

In view of the current environmental health situation, the decision of the government of Pakistan to establish and launch the environmental health protection unit is very timely and a positive step towards improving environmental health in the country. The unit can act as the front end leader that will play a pivotal role in protecting and promoting safer and healthier life in the country.

\section{References}

1. Population projections (1998-2023). Islamabad, Pakistan, National Institute of Population Studies, 2000.

2. Pakistan strategic country environmental assessment. Islamabad, South Asia Environment and Social Unit, World Bank, 2006.

3. Country profiles. Cairo, World Health Organization, 2009 (http://www.emro.who.int, accessed 5 May 2010).

4. The gazette of Pakistan: Pakistan environmental protection act, 1997. Lahore, Environment Protection Department Punjab, 1997 (No. F.9(46)/97-Legis).

5. Ustun AP, Corvalan C, eds. Preventing disease through healthy environments: towards an estimate of the environmental burden of disease. Geneva, World Health Organization, 2006.

6. Kahlown MA, Tahir MA, Rasheed R, eds. Fifth water quality monitoring report 2005-06. Islamabad, Pakistan, Council for Research in Water Resources, Ministry of Science and Technology, 2008.

7. The world health report 2002: reducing risks, promoting healthy life. Geneva, World Health Organization, 2002.

8. Demographic and health indicators for countries of the Eastern Mediterranean. Cairo, World Health Organization, Regional Office for the Eastern Mediterranean, 2004 (201 WHO-EM/ HST/181).

9. Report 1998-2003. National Institute of Health, Public health laboratories, epidemic investigation cell, [Website] (http:// www.nih.org.pk/eic.asp, accessed 22 May 2010).

10. National standards for drinking water quality (NSDWG). Islamabad, Pakistan, Environmental Protection Agency, 2008.
11. Pakistan's water at risk. Water and health related issues in Pakistan \& key recommendations. A special report. Islamabad, Pakistan, World Wide Fund For Nature Pakistan, 2007 (http://www. wwfpak.org/pdf/water-report.pdf, accessed 22 June 2010).

12. Annual progress report for the year 2007-08. Islamabad, Pakistan, Health Services Academy, Ministry of Health, 2009.

13. Waste from health care activities Geneva, World Health Organization, 2007 (WHO Fact Sheet, No. 253). (http://www.who. int/mediacentre/factsheets/fs253/en/print.html, accessed 3 May 2010).

14. The gazette of Pakistan: hospital waste management rules Pakistan 2005.Islamabad, Pakistan, Ministry of Environment, 2005 (S.R.O.1013(1)/2005).

15. Hospital waste factsheet. Islamabad, Pakistan, World Wild Fund for Nature Pakistan, [Website] (http://www.wwfpak.org/ factsheets_hwf.php, accessed 22 June 2010).

16. Javied-Sabiha, Tufail M. Heavy metal pollution from medical waste incineration at Islamabad and Rawalpindi, Pakistan. Microchemical Journal, 2008, 90(1):77-81.

17. National health policy 2009 (draft 3 ): stepping towards better health. Islamabad, Pakistan, Ministry of Health, 2009.

18. WHO Food Safety Programme. Geneva, World Health Organization, 2009 (http://www.who.int/foodsafety, accessed 10 April 2010).

19. The gazette of Pakistan: national environmental quality standards for motor vehicle exhaust and noise. Islamabad, Pakistan, Ministry of Environment, 2009. 